\title{
Problems in Operation and Management of Farmer Managed Irrigation Systems in Nepal \\ - A Case Study of Kumroj FMIS in Chitwan District -
}

\author{
Nirmala Devi Bhatta ${ }^{1}$, Atsushi Matsuoka ${ }^{2}$ and Arjun Kumar Shrestha ${ }^{3}$
}

\begin{abstract}
This study was carried out during April-May, 2005 to explore the management and operation of the Kumroj FMIS, one of the Farmer Managed Irrigation Systems operating (FMIS) in three village development committees (VDCs) of the eastern Chitwan district, Nepal. The Kumroj FMIS committee is responsible for the operational and managerial affairs of the system while the East Rapti Water Users Association is the apex body that provides major/external financial help for this system including all the FMISs in that area. This system delivers service to the beneficiaries on an unbiased and transparent manner. The rights, rules, and duties related to operation and management are entirely under the control of the water users themselves. In this system, water in each branch canal is allocated depending upon the area and type of land to be irrigated as well as the season. The irregular water supply resulting from the unlined canals is the major constraint encountered in the effective service delivery of this system. Further, the tail users receive less of the irrigation water as compared to the head users. The practice of labor mobilization based on households utilizes little technology. Proper repair and maintenance as well as canal improvement work is of utmost important to reduce the conveyance loss. The administrative work, especially communication, is heavily dependent on Panipale (water guards), hindering the smooth operation of system. Therefore, restructuring the administrative framework as well as improving the canals is of utmost importance for the sustainable and effective functioning of Kumroj FMIS.
\end{abstract}

Keywords: FMIS; water distribution; canal repair; Panipale; head users; tail users

\section{Introduction}

Irrigation is considered the key to the improvement of the existing agriculture production system in Nepal as envisaged in various plans and policies of the Nepalese government. In Nepal, only 20 percent of the cultivated area is under irrigation and farmer managed irrigation systems account for over 70 percent of that (APP, 2004). Mainly three types of irrigation systems are operating in Nepal: the Government Managed Irrigation System (GMIS), the Farmer Managed Irrigation System (FMIS) and the Joint Managed Irrigation System (JMIS) (Khanal, 2003). Farmer Managed Irrigation Systems, FMIS, are the oldest and most indigenous irrigation providers in Nepal. Farmers in different geographical areas have evolved these systems over a long period of time. FMIS now contributes substantially to the agricultural production of the country. It is estimated that about 1,500 FMIS are operating in the hills area with another 1,700 in the terai (plains) area and they contribute to $40 \%$ of the food production in Nepal (Dhakal et al., 1998). Contrasted to GMIS, FMISs are low cost, based on local resources and have the ability to respond and mobilize the required resources for the maintenance and upkeep of the systems. Hence, FMISs have played a pivotal role in

\footnotetext{
${ }^{1} \mathrm{Ph} . \mathrm{D}$ Student, The United Graduate School of Agriculture Sciences, Ehime University, 3-5-7 Tarumi, Matsuyama, Ehime 790-8566, Japan (Corresponding Author) E-mail: bhatta_nirmala@yahoo.com

Associate Professor, Faculty of Agriculture, Ehime University, 3-5-7 Tarumi, Matsuyama, Ehime 790-8566, Japan

${ }^{3}$ Assistant Professor, Institute of Agriculture and Animal Sciences, Rampur Campus/T.U., Nepal
}

sustaining the rural as well as the national economy of Nepal and therefore, have assumed a dominant role in the irrigated agriculture of the country. These systems are constructed, improved over a period of time and managed by the beneficiary farmers themselves. Recognizing the superiority of FMIS over the agency managed irrigation systems in various aspects, the Nepalese government has adopted the policy to reduce its role in the management of irrigation systems. Consequently, the government pursues management transfer programs to reduce their expenditures on irrigation, improve agricultural productivity and stabilize the deteriorating irrigation systems.

Water as community property, utilized with organizational autonomy and collective action are hallmarks of FMIS. Management of the irrigation system involves the social, economic and institutional aspects related to production, acquisition, allocation and distribution of irrigation water. These aspects have been found to be greatly influenced by environmental conditions as well as the social structure prevailing in a particular region or location. Nonetheless, FMISs are also confronted with several constraints, especially related to the operation and management of the system for effective delivery of irrigation water that may consequently influence their sustainability if not adequately addressed in time.

Chitwan, representing an inner Terai of Nepal, is one of the potential domains for agriculture. An abundance of water resources and a large number of indigenous complexes, 
irrigation systems (more than 88) exist in East Chitwan valley (Shukla and Sharma, 1993). The contribution of FMIS to the total irrigated area of Chitwan district is about 58.4\%. Among various FMIS in Eastern Chitwan, Kumroj FMIS is one of the oldest systems, covering three village development committees. Bhatta et al. (2007) reported that this FMIS is responsible for considerable improvement with respect to the area under irrigation, crop productivity and cropping intensity in the command area. Furthermore, they have recommended exploring the problems being faced in the operation and management of this FMIS.

Therefore, the main aim of this paper is to explore the major operational and managerial problems the beneficiaries are confronting in this irrigation system. Further, possible solutions are suggested to mitigate these constraints for efficient and sustainable functioning of this FMIS.

\section{Methodology}

\subsection{Selection of the study area and irrigation system}

The multistage sampling method was employed in this study. The eastern part of the Chitwan district under the Rapti River Basin was selected due to the large numbers of farmer managed irrigation systems running in this area. In the beginning phase, a meeting of the key persons from the East Rapti Water Users Association (Purbi Rapti Jal Upabhokta Samiti in local term) was organized to select the appropriate irrigation system. East Rapti Water Users Association is the apex body that is responsible for formulating the major rules and regulations of all the FMISs operating in the East Chitwan. Kumroj FMIS was selected considering the extensive coverage of the system (Figures 1 and 2).

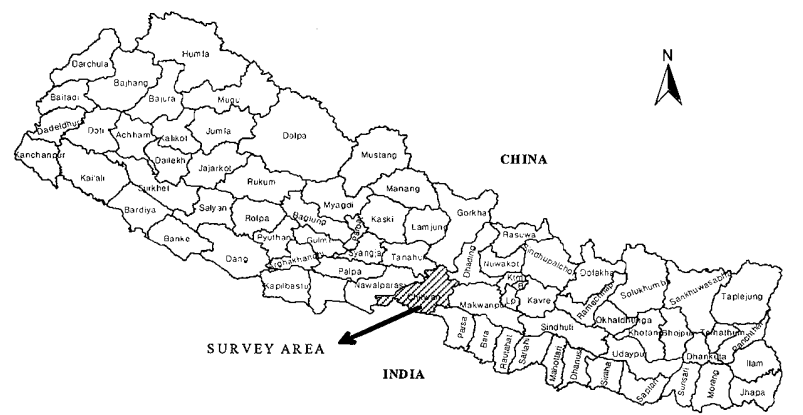

Figure 1: Map of Nepal showing the survey area

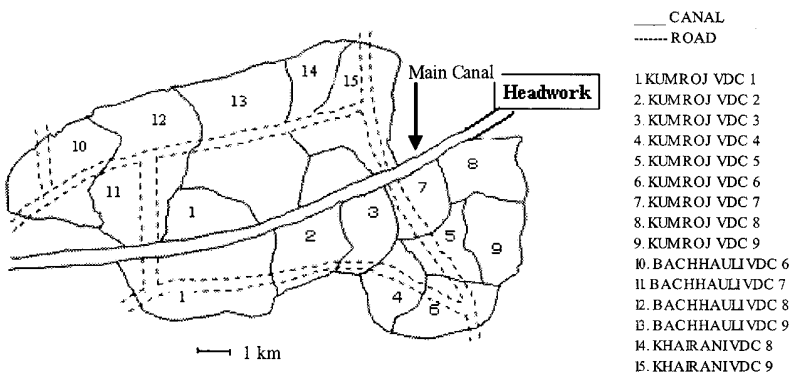

Figure 2: Schematic diagram of Kumroj Irrigation System

2.2 Collection and analysis of data

Both primary and secondary sources of information were used in the study. Kumroj, Khairani and Bachhauli Village
Development Committees (VDCs) are the command areas of this system selected for this purpose. A pre-tested semi-structured questionnaire was prepared and used to collect primary information from the farmers. Altogether 100 respondents, encompassing beneficiary farmers in FMIS were randomly selected from the three VDCs. Officials from Department of Irrigation (DOI) and VDCs were interviewed as key informants about the performance of FMIS. Secondary sources also included both the published and unpublished documents and reports from the Ministry of Agriculture and Co-operatives. Cross referencing of these sources and overlapping in the interview design provided a means of data triangulation.

The use of flexible interview techniques gave the respondents greater autonomy to discuss their views and their own priorities while a systematic attempt was made by the researcher to fully cover the predefined areas of interest. The field investigation was carried out during April-May, 2005 , focusing on the years 2002-2003 time frames. The data collected were coded, processed, classified and analyzed using appropriate statistical tools.

\section{Results and discussion}

\subsection{History and command areas}

The Kumroj Farmer Managed Irrigation System (Kumroj FMIS) is one of the earlier irrigation systems in the Chitwan district in which the management of the system was transferred to the users. Although there is no systematic documented history, the water user committee (WUC) reported that this FMIS was established a long time ago but was officially registered by government of Nepal only on 1981. The main canal of this FMIS runs over $21.5 \mathrm{~km}$ in length, serving 838 households. This irrigation system is a gravity flow system directing water from the Rapti River as the main source. The command area of this system extends in three VDCs, Kumroj, Khairani and Bachhauli, with a total irrigated area of 1229.90 ha. Among these three VDCs, the largest area lies within the Kumroj VDC, i.e. 678.1 ha followed by Bachhauli and Khairani, with 436.2 and 115.2 ha respectively. The major crops grown in the study area are rice, maize, wheat, mustard and vegetables. Over time, this FMIS has resulted in the significant changes in the area under irrigation, as seen in the cropping pattern as well as the crop productivity in the command area (Bhatta et al., 2007).

\subsection{Operation and management: Status and constraints} A two-tier irrigation organization is operating in this irrigation system. At the topmost level the East Rapti Water Users Association is involved in the formulation of major rules, regulations and policy required for the operation of the entire farmer managed irrigation systems in this region. This acts as the apex body with representation from 88 different irrigation systems including this Kumroj FMIS. The eastern part of Chitwan district, where this system is located, is characterized by an intense network of several FMISs. At the lowest level, the Kumroj FMIS committee is formed among the irrigators of sub canals of this irrigation 
system. This committee concentrates mainly on routine operation with respect to distribution of irrigation water, collection of water fees, distribution and mobilization of resources (including loans to the beneficiaries), minor repairs and maintenance of canals as well as conflict resolution, as shown in Figure 3. This committee also acts as the connecting link between the East Rapti Water Users Association and the water users of this FMIS. The East Rapti Water Users Association has to deal with the major repair work of the irrigation system, external donation to this FMIS and also the severe conflicts which occur in the FMIS.

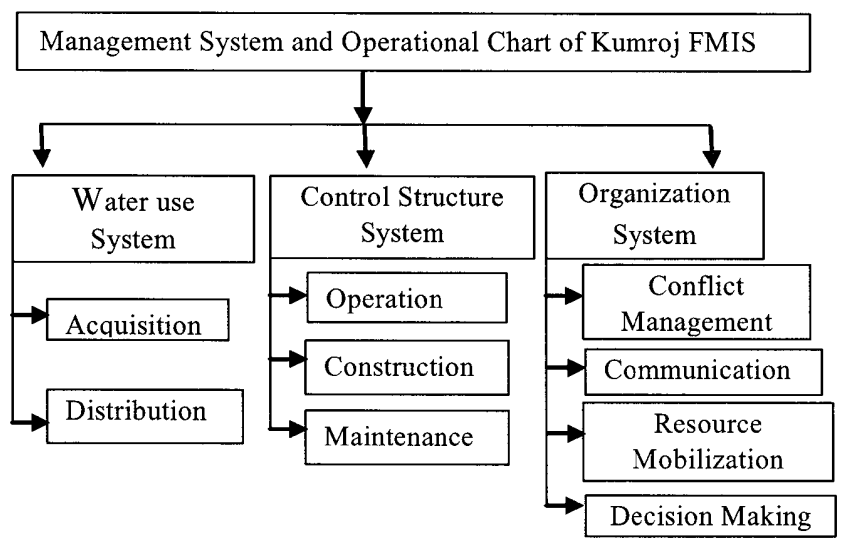

Source: FMIS office of Kumroj

Figure 3: Management System and Operational Chart of Kumroj FMIS

\subsubsection{Water allocation and distribution}

Water distribution means the physical delivery of water to the field as per water allocation. Water in each branch canal is allocated depending upon the area and type of land to be irrigated as well as the season. A more or less similar system of water allocation was obtained in the Khalle Dan- dakhet Kulo FMIS in the Baglung district of Nepal (Pun, 2001). During the rainy season, when rice is cultivated in the field, water availability is not as problematic as in other seasons. In the rainy season, water distribution is continuous while in other seasons it is rotated to every user in proportion to the land area, land type and crop. Thus, this irrigation system is characterized by a fully adjustable water distribution system since the irrigation water is delivered to the farmers based on the combined criteria of available supply, crop need and land type. All the beneficiaries have an equal chance to irrigate their paddy during the rainy season, as well as other crops growing in the respective seasons. Therefore, all the farmers in the command area have equal rights in the distribution of water, but the volume of water supplied depends on the land area. In $\mathrm{Ku}$ mroj FMIS, the process of water distribution is practiced in accordance to the water allocation system adopted by the local people. Water is distributed among the sub-canals which are constructed to make quick and easy distribution of water in the command area.

\subsubsection{Rules in use for water distribution in Kumroj FMIS}

All users of this FMIS have to pay an Irrigation Service Fee (ISF) in advance twice a year, a maintenance fee in the form of labor, membership and membership renewal fees, before they place demand for acquiring water. At present, the beneficiaries have to pay ISF@NRs.3000/ha twice a year (NRs indicates Nepalese currency and the exchange rate is NRs. $5.70=¥ 10$ ).

The committee collects irrigation request form from users through the chairpersons of their respective branches. The user fills out the demand form, shown below in Figure 4 , and submits the completed form to the chairman of his respective branch committee or sometimes also to the $\mathrm{Pa}$ nipale (water guard) and he forwards this form to the committee. (The Panipale is the local term used to refer to an

\begin{tabular}{|c|c|c|c|c|c|c|c|c|}
\hline $\begin{array}{l}\text { To .... } \\
\text { Subjec } \\
\text { Sir, } \\
\text { Kin }\end{array}$ & $\begin{array}{l}\text { Irrigati } \\
\text { y make }\end{array}$ & labl & igatio & tion $\mathrm{R}$ & est For & hrs/minute a & tated bel & \\
\hline S.No & Name & & Brar & $p(s)$ & Area & $\begin{array}{r}\text { I } \\
\text { Time }\end{array}$ & $\begin{array}{l}\text { ation } \\
\text { requency }\end{array}$ & Remarks \\
\hline $\begin{array}{l}\text { Demar } \\
\text { Date: }\end{array}$ & made b & & $\ldots \ldots$ & & & & & $\begin{array}{l}\text { proved by: } \\
\text { signation: }\end{array}$ \\
\hline & & & & & ibution & ormat & & \\
\hline S.No & Date & & $\mathrm{hNo}$ & & Period & Irrigation & Crop & Remarks \\
\hline & & & & $\begin{array}{l}\text { Beg } \\
\text { Date }\end{array}$ & $\begin{array}{l}\text { ing } \\
\text { Time }\end{array}$ & $\begin{array}{l}\text { Closing Date } \\
\text { and Time }\end{array}$ & & \\
\hline $\begin{array}{l}\text { Secret } \\
\text { Date: }\end{array}$ & & & & & & & & $\begin{array}{l}\text { hairman: } \\
\text { ate: }\end{array}$ \\
\hline
\end{tabular}

Figure 4: Water Distribution Request Form 
appointed staff member of the system. He/she is mainly involved in water distribution and communication. Among the users the executive committee selects one of the applicants on the basis of general experience). The committee examines these forms to adjust the rotation between branches and also the users within the same branch. The committee allocates water and develops a water distribution schedule. Thereafter, the Panipale communicates the schedule to all concerned users and also distributes the water as per the approved schedule. In the case of water stealing, or if users do not follow the schedule, the committee will impose a fine equivalent to double the Irrigation Service Fee (ISF). If the same person commits the same offense a second time, the amount of the penalty doubles. The committee has the authority to cease the water supply to those users who commit an offense more than twice. However, no serious or multiple offenses were noticed in this FMIS.

\subsubsection{Canal repair and maintenance}

The main resource for the repair and maintenance of this system is labor mobilization among users. The major portion of the canals of the Kumroj FMIS is earthen, although a certain portion is concrete. Regmi (2007) reported that most of the branch canals in the majority of the systems in East Chitwan are unlined. The intake of the irrigation system is regulated by a permanent regulator (a concrete structure regulated by an iron key installed at the entrance of the main canal used to regulate water volume in the system) and supported by the gabion box structure (stone-filled wire netting made of galvanized aluminium wire and adhered to both sides of the entrance of the main canal). Major repair and maintenance work consist of annual desilting and regular preventive maintenance of the main and branch canals while emergency repair work consists of the repair of the canals after major flood damage. The committee of the Kumroj FMIS has the authority to mobilize labor from among the users for all these repair and maintenance activities. This committee also approaches the East Rapti Water Users Association for major repair work that requires a large monetary investment.

The repair and maintenance of the intake and major canal is jointly held by all the users of the FMIS at least twice a year. In general, the first repair work is carried out before the monsoon season begins, i.e. the second week of Asadh (June-July), while the other is carried out before Chaitra (Feb-March). For the main canal desilting, a particular date is selected by the main committee of FMIS. The Panipale, committee members and also the users communicate that date among themselves. The desilting and maintenance work of the sub-canals are carried out by the users of those sub-canals.

For desilting as well as the repair and maintenance work, labor is mobilized on a household basis. Irrespective of the landholding size, each household is requested to contribute one person per day until the repair and maintenance is completed. Those absentee beneficiaries who do not contribute to the labor resource at the time of repair and maintenance are fined the cash equivalent of the prevailing labor charge.

\subsubsection{Administrative management}

The Kumroj FMIS committee is responsible for the administrative affairs of the irrigation system. This committee of 13 members is formed during the general assembly of the water users once a year. These executive members are democratically elected through the general assembly of the beneficiaries, each member representing the respective branch canal Figure 5. Thereafter, one among these executive members will be unanimously selected as the chairman of the organization.

Routine management activities such as communication regarding the water distribution schedule, repair, maintenance, funding and labor mobilization are the major activities of this committee. This body is also responsible for maintaining the working relationship with the East Rapti Water Users Association related to major/external financial help for canal improvement and the regulatory mechanism of FMIS. In general, the East Rapti Water Users Association provides financial assistance to the all member FMIS operating in eastern Chitwan depending upon the extent of the major repair work to be carried out in the respective system. The chairman of the Kumroj FMIS maintains the record keeping of the system related to administrative and financial activities. The Panipale, who also does some official work, is the only salaried staff member of the system. To appoint a Panipale, the executive committee posts an

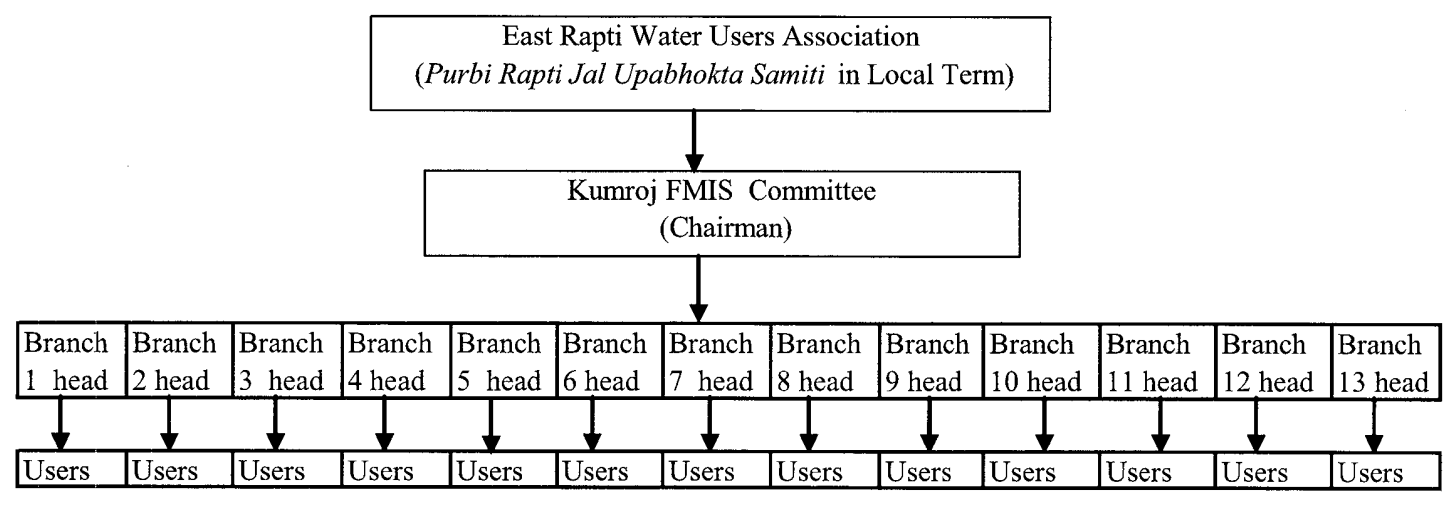

Figure 5: Organizational Chart of Kumroj FMIS 
advertisement on the notice board of the office. Only the beneficiaries of the system are eligible to apply for the post. The executive committee selects one of the applicants on the basis of general experience. Panipale mainly helps in water distribution and communication regarding the imposition of rules and regulations such as labor mobilization for the repair and maintenance of the system.

\subsubsection{Conflict resolution}

The management of conflict has been an integral part of the operation and management in this system. Conflict is the manifestation of competition, arguments, or disputes with a physical threat, or fighting, and war and so on. It is a universal phenomenon that if two groups simultaneously possess the rights to use material resources, conflict will arise in its use. In the Kumroj FMIS, the major cause of conflict arises from free riding and violation of rules specifically related to the water rights, turn overlapping, and water stealing and canal encroachment. Similarly, the conflict cases related to the system and its operation and maintenance are of a simple nature and are resolved at the farmer's level under mutual consensus.

The respondents recall that 2 years before, there was a major conflict among the users of the tail end of the canal that erupted into a physical fight due to scarce availability of irrigation water. This was an instance when the conflict could not be resolved within the Kumroj FMIS and was later transferred to and resolved by the East Rapti Water Users Association.

\subsubsection{Fund mobilization}

The major sources of funds in the Kumroj FMIS include the registration/membership fee, annual renewal fee, Irrigation Service Fee (ISF), external grants from governmental and non-governmental organizations, cash fines from the users absent during repair and maintenance work and also from those who commit an offense regarding the usage schedule. In addition, interest obtained from the loan is another source of funds of this FMIS. The executive committee of the Kumroj FMIS is responsible for the mobilization of funds. Further, the chairman of this FMIS maintains all the financial records regarding the fund use. The record keeping is transparent and is annually audited by an authorized auditor.

\subsection{Problems encountered}

In this FMIS, the beneficiaries are confronted with several problems that have considerable bearing on the efficient functioning of the system. The major constraints prevalent among the users are depicted in Figure 6. From the perusal of this figure it is apparent that the problem related to water supply is prominent in this FMIS along with the mobilization of financial resources and also administrative activities.

\subsubsection{Water allocation and distribution}

A significant proportion of the respondent farmers (89\%) pointed out an irregular supply of irrigation water as the main constraint they were facing while irrigating their field Figure 6. Further, a significant proportion of the users complained that the supply is not reliable. Such irregular water supply in this FMIS may be due to poor technical know how in the construction of the canal, insufficient repair and maintenance of the irrigation system and also an unscientific operational and distribution system.

The irregular water supply prevalent in this system results in dispute over water distribution. A majority of the beneficiaries, i.e. $62 \%$, reported disputes over the supply of water as prominent in this FMIS. The dispute over the distribution of irrigation water is a characteristic feature as well as an unsolved problem of many irrigation systems in Nepal. Paudel (2000) reported that the dispute in FMIS generally arise due to water use activities and resource mobilization. In the context of limited supply, every farmer wants a greater volume of water for irrigation, leading to
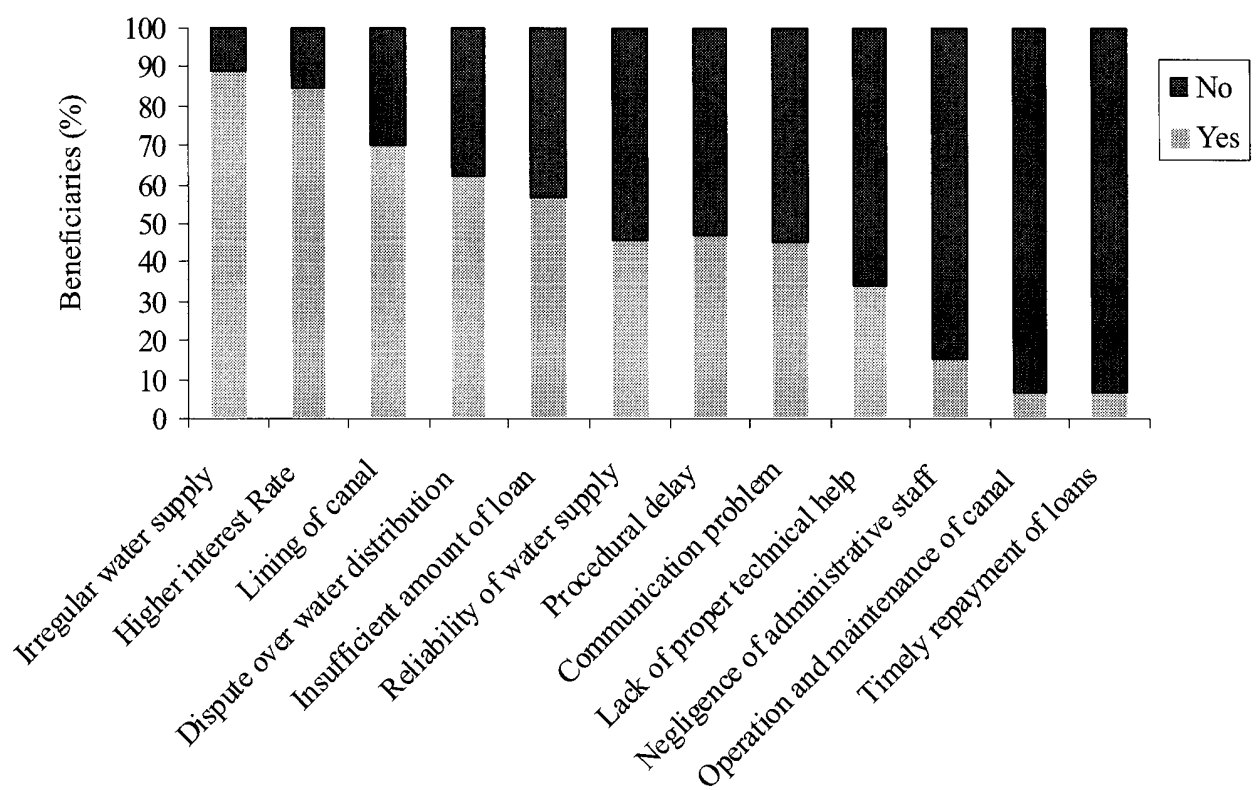

Figure 6: Major Constraints of Kumroj FMIS 
conflict among the members. Those who are socially strong and influential were using as much water as they could while the weaker ones did not have a place to complain and regain their rights over the irrigation. Specifically, the beneficiaries located at the tail end of the irrigation system suffered more from problems related to irregular water supply, unreliability of water supply and the dispute over water distribution, as evident in Table 1. This is because a

Table 1: Categorization of the users with complaints

\begin{tabular}{|l|c|c|}
\hline \multirow{2}{*}{ Nature of the Problem } & \multicolumn{2}{|c|}{$\begin{array}{c}\text { Category of respondents } \\
\text { with complaints }\end{array}$} \\
\cline { 2 - 3 } & $\begin{array}{c}\text { Tail Users } \\
(\%)\end{array}$ & $\begin{array}{c}\text { Head Users } \\
(\%)\end{array}$ \\
\hline Irregular water supply & 78 & 22 \\
\hline $\begin{array}{l}\text { Dispute over water distri- } \\
\text { bution }\end{array}$ & 70 & 30 \\
\hline Reliability of water supply & 65 & 35 \\
\hline Lining of the canal & 53 & 47 \\
\hline $\begin{array}{l}\text { Regular operation and } \\
\text { maintenance of canal }\end{array}$ & 51 & 49 \\
\hline Communication & 72 & 28 \\
\hline
\end{tabular}

Note: Users at the lower/tail end of a main canal are termed as tail users while those at the head end are head users

major portion of the canal is earthen, resulting in greater conveyance loss, especially during the spring and winter season, when the intake as well as the flow of irrigation water is substantially reduced in the canal. As a result, water availability will gradually decrease towards the tail end of the system. In general such disputes are generally solved through discussion among the concerned parties in a meeting of the executive committee of FMIS and also through a general mass meeting of the users later on. There are very few occasions when the disputes could not be resolved in Kumroj FMIS and had to be settled by the East Rapti Water Users Association.

To strengthen the allocation and distribution of this FMIS, it is imperative to improve the canal structure to make the supply more regular and reliable. Further, managerial aspects including proper guidelines should be formulated democratically and followed to avoid such disputes which might affect the operation of FMIS.

\subsubsection{Lining, operation and maintenance of canal}

The quality of the canal structure significantly influences the delivery of irrigation water in the system. In this FMIS, $70 \%$ of the farmers complained about unlined canal since a major portion of the main and branch canals are earthen, resulting in greater seepage of water, and frequent breakage of the bunds. Further, $93 \%$ of the beneficiaries were dissatisfied with repair and maintenance of the canals.

From Table 1, it is apparent that problems related to lining, operation and maintenance of the canal are suffered equally by all users, i.e. the users from both the head and tail ends. During the survey period, the author could not determine the maintenance routine of the irrigation system. Such inappropriate maintenance of these canals may be due to lack of sufficient funds as well as lack of technical knowledge of the local people. It is noteworthy to mention that many users reflected their dissatisfaction over the technical help in this system.

In general, almost all of the beneficiaries were involved in the annual repair and maintenance work of the canal and sub-canal, especially during Asadh (June-July), while comparatively more absentees were reported in the repair work carried out in other season i.e. before Chaitra (Feb.-March). This may be due to the fact that June-July is the season to transplant monsoon paddy which is the main staple crop in the command area. Further, the availability and reliability of water is significantly improved in that season. However, during summer all the households, especially tail users, may suffer from a reduced volume of water due to a decrease in the water availability in the system. As a consequence, some tail users may not participate in the repair work in that season. Further, there is great dissatisfaction, especially among the small land holding users and also medium land holding farmers, regarding the basis of labor contribution in the repair and maintenance work.

\subsubsection{Fund Mobilization}

Proper mobilization and efficient utilization of financial resources is the key factor of any irrigation system. In this FMIS, a large number of farmers (57\% of the respondents) complained that the amount of loan they receive was not enough to purchase all the necessary inputs Figure 6 . The majority of the respondents were small scale and resource poor farmers who were interested in expanding their cultivation and also to introduce cost intensive modern technology, but could not do so because of limited financial capital. As a consequence, the productivity of the farms was also being affected by late delivery of farm inputs. This indicates the necessity to provide greater access to credit organizations to enable farmers to buy all the necessary farm inputs. However, a majority of the water users believe that they are not late with their loan payments. In the study area only $7 \%$ of the respondents reported a delay in repaying their loans to the FMIS.

From Table 2, it is evident that the farmers holding a large land area are more critical about the insufficient amount of the loans provided by the FMIS. This may be due to the fact that farmers with a larger land area needs more inputs and hence requires more investment in the cultivation of crops. On the other hand, the small landholding farmers are more critical about the higher interest rate they have to pay to FMIS.

The users also complained about the delay in loan procedures adopted by the main committee of Kumroj FMIS. But Table 2 indicates that there is no disparity among the respondent farmers on the basis of landholding size while delivering the loan service of FMIS.

\subsubsection{Administrative Management}

It was found out that a procedural delay in various routine activities, such as regular maintenance work and registra- 
Table 2: Categorization of the users with complaints

\begin{tabular}{|l|c|c|c|}
\hline \multirow{2}{*}{ Nature of the Problem } & \multicolumn{3}{|c|}{$\begin{array}{c}\text { Category of respondents (\%) } \\
\text { according to landholding size }\end{array}$} \\
\cline { 2 - 4 } & $\begin{array}{c}\text { Large } \\
(>1 \text { ha })\end{array}$ & $\begin{array}{c}\text { Medium } \\
(0.6-1 \mathrm{ha})\end{array}$ & $\begin{array}{c}\text { Small } \\
(<0.6 \mathrm{ha})\end{array}$ \\
\hline Higher interest rate & 25 & 33 & 42 \\
\hline $\begin{array}{l}\text { Insufficient amount of } \\
\text { loan }\end{array}$ & 58 & 23 & 19 \\
\hline Procedural delay & 30 & 34 & 36 \\
\hline $\begin{array}{l}\text { Lack of proper tech- } \\
\text { nical help }\end{array}$ & 32 & 35 & 33 \\
\hline $\begin{array}{l}\text { Negligence of admin- } \\
\text { istrative staffs }\end{array}$ & 31 & 35 & 34 \\
\hline $\begin{array}{l}\text { Regular operation and } \\
\text { maintenance of canal }\end{array}$ & 10 & 24 & 66 \\
\hline
\end{tabular}

Note: This categorization is based on the existing landholding size of the study area

tion of new membership, seriously affected the performance of FMIS. About $47 \%$ of the beneficiaries reported this problem as a serious one. Farmers willing to participate in this FMIS had not joined on time because it took time to be accepted as users due to delay in administrative procedures. In the Kumroj FMIS, the chairman, as well as other executive members, serves as a volunteer in this system without receiving any kind of facility and/or allowance Naturally, they provide their extra time only after fulfilling their personal endeavors. Only one person, the Panipale, is paid mainly because of the limited source of income and the Panipale is mainly entrusted to activities related to the implementation of water allocation and distribution schedule. This may have resulted in the procedural delay in administrative affairs. Further, the executive members and the Panipale lack technical training related to their work.

The members involved in record keeping lacks the technical skills in performing the activity and it obviously results in procedural delays. Similarly, lack of technical knowledge in repairing the specialized equipment renders the system less effective, causing sever shortage of irrigation water during the peak season and that making the situation more open to dispute among the beneficiaries. The procedural delay may also be due to the lack of farmer oriented and sound management planning in the system. However, only $15 \%$ of the farmers complained about the negligence of administrative staff in spite of the fact that there is considerable procedural delay in FMIS. It indicates that the executive committee is working in a transparent and unbiased manner. All the users may be convinced that the executive members are serving them voluntarily in the best way they can, although there is still room to improve their working methodology. Very few instances were reported when the administrative staff did not follow the approved schedule properly, and were absent from their work without informing the office. A perusal of Table 2 clearly pointed out that there was no discrimination among water users with respect to land holding size while providing technical and other administrative assistance.

During the interview time, $45 \%$ of the farmers pinpointed the need to have a more effective communication system to deliver decisions/messages to the users about desilting, repairing, and maintenance, as well as a mass meeting to discuss the operation of the canals and the sub-canals during crop cultivation and irrigation activities. The problem in timely communication to the users might have arisen due to the shortage in the supporting staffs in the Kumroj FMIS as compared to the beneficiary households. In addition, the communication problem is greater among the tail users than the head users. Such difference with respect to the location of land may be due to the fact the main office of the FMIS is located at the head end and also the Panipale who is responsible for communication resides at the head end of the canal system.

\subsubsection{Summary of the analysis of the problems of opera- tion and management of FMIS}

We have conceptualized and presented a summary related to the problems encountered in this FMIS in Table 3.

\section{Conclusion and recommendation}

The Farmer Managed Irrigation System is one of the successful irrigation systems in the Eastern Chitwan in the present context. Smooth running of this FMIS is important in the study area since this system has wide coverage and the main source of income in this area is farming. We found that this FMIS is operating on an unbiased and transparent manner as there is no disparity among the large and small land holding farmers regarding the delivery of service to the beneficiaries. The rights, rules, and duties are entirely under local control with water users themselves defining the role and duties for operation and management. But the users at the tail end are more deprived of irrigation water compared to the head end users, although this is not immediately apparent.

The irregular supply of irrigation water resulting from the unlined canals is the major bottleneck in the effective service delivery of this system. To deal with this and other problems associated with water availability in the system, there should be regular maintenance of the system to minimize the conveyance loss. The existing system of labor mobilization based on households should be based on land holding size, which would be fairer. Further, creation of funds for repair and maintenance work especially that for emergency repair work, is of utmost importance. Not only for fund raising, there is a need to develop a strong management plan as the water users are also not fully satisfied with the administrative activities of the FMIS. Prompt decision making and the effective communication of decisions ensures a higher degree of compliance to the decision. The authors revealed that the administrative work, especially communication, is heavily dependent on Panipale in the Kumroj FMIS, which may, impede the operation of the system. Therefore, the administrative framework should be restructured taking these suggestions into account. To deliver technical services, such as canal improvement, and other operational services, such as account keeping re- 
Table 3: Summary of analysis of problems in the operation and management of FMIS

\begin{tabular}{|c|c|c|c|}
\hline $\begin{array}{l}\text { Operation and Man- } \\
\text { agement }\end{array}$ & Nature of Problem & Cause of Problem & Remarks \\
\hline Water Use system & $\begin{array}{l}\text { *Irregular water supply. } \\
{ }^{*} \text { Dispute over water distri- } \\
\text { bution. } \\
{ }^{*} \text { Reliability of water } \\
\text { supply. }\end{array}$ & $\begin{array}{l}\text { * Significant portion of canal is } \\
\text { earthen and unlined. } \\
{ }^{*} \text { Conveyance loss is greater. } \\
\text { * Low use of available technology } \\
\text { in the Water distribution system. }\end{array}$ & $\begin{array}{l}\text { *Problem intensifies } \\
\text { during summer and } \\
\text { spring. } \\
\text { *Tail users suffer more } \\
\text { than head users. }\end{array}$ \\
\hline $\begin{array}{l}\text { Control Structure } \\
\text { system }\end{array}$ & $\begin{array}{l}\text { *Lining of the canal. } \\
* \text { Regular operation and } \\
\text { maintenance of canal. } \\
* \text { Lack of technical skill. }\end{array}$ & $\begin{array}{l}\text { *Capital investment is low. } \\
\text { * Majority of beneficiaries are } \\
\text { small scale and poor. } \\
\text { *The administrative staffs are de- } \\
\text { void of technical training. }\end{array}$ & $\begin{array}{l}\text { *In general, the bene- } \\
\text { ficiaries contribute } \\
\text { labor for regular repair } \\
\text { and maintenance work } \\
\text { twice in a year. }\end{array}$ \\
\hline Organization system & $\begin{array}{l}\text { *Procedural delay. } \\
* \text { Negligence of administra- } \\
\text { tive staffs. } \\
{ }^{*} \text { Communication problem. } \\
{ }^{*} \text { Higher interest rate and } \\
\text { insufficient amount of loan. }\end{array}$ & $\begin{array}{l}\text { *The executive members work } \\
\text { voluntarily. } \\
\text { *In the system, the only paid staff } \\
\text { member is Panipale, due to limited } \\
\text { income source. } \\
\text { *The collected fund for mobiliza- } \\
\text { tion is comparatively small com- } \\
\text { pared to number of beneficiaries } \\
\text { and demand. }\end{array}$ & $\begin{array}{l}\text { *The Panipale is heav- } \\
\text { ily burdened with ad- } \\
\text { ministrative works. } \\
{ }^{*} \text { Communication } \\
\text { problem is intense in } \\
\text { tail end. } \\
\text { *The management plan } \\
\text { is not sound as well as } \\
\text { documented. }\end{array}$ \\
\hline
\end{tabular}

quired for the effective operation of the system, a training program should be conducted of the users. As a significant proportion of the farmers in the study area are illiterate, the management plan as well as the training should be more hands on and easy to implement.

\section{Acknowledgements}

We are grateful to Prof. Takao Hosokawa and prof. Hu Bai for their healthy comments. The authors would like to thank Atsushi Yada whose computer expertise contributed significantly in preparing the manuscript.

\section{References}

[1] APP (2004): Agriculture Perspective Plan, His Majesty's Government of Nepal, Ministry of Water Resources, Department of Irrigation, Jawalakhel, Kathmandu, Nepal, pp. $1-20$.

[2] Bhatta Nirmala D., Atsushi Matsuoka and Atsushi Yada (2007): Changes in Agricultural Production and Productivity under Farmer managed Irrigation System in Nepal, Journal of Rainwater Catchment System Vol.13 No.1. pp. 17-22.

[3] CBS, HMG/NPC (National Planning Commission) (2004): Statistical Pocket Book Central Bureau of Statistics, Ramshah Path, Thapathali Kathmandu Nepal, 294 p.

[4] Dhakal, B. P., Atsushi Matsuoka and Tokusou Saitou (1998): Water Management by Farmers in Nepal, Journal of Rainwater Catchment System Vol.4 No.1. pp. 23-28.

[5] Economic Survey (2004 -2005): Economic Survey Fiscal Year 2004/2005. His Majesty's Government, Ministry of Finance, HMG, Ministry of Finance, Singh Durbar, Kath- mandu, Nepal, $288 \mathrm{p}$.

[6] Khanal, P. R. (2003): Engineering Participation, The Process and Outcomes of Irrigation Management Transfer in the Terai of Nepal, Wageningen University Water Resources Series, Baba Barkha Neth, New Delhi, 335p.

[7] Lam, Wai Fung (1996): Improving the Performance of Small Scale Irrigation Systems: The Effects of Technological Investments and Governance Structure on Irrigation Performance in Nepal, World Development, 24 (8) pp. 1301-1315.

[8] Paudel, R. (2000) Farmers' Law and Irrigation. Water Rights and Dispute Management in the Hill of Nepal. Erasmus Universities Rotterdam.

[9] Pun, L. P. (2001): Challenges to Farmer Managed Irrigation System, Proceeding of international Seminar, Farmer Managed Irrigation System Promotion Trust, Min Bhawan, Kathmandu, Nepal, pp. 74 -99.

[10] Regmi A. R. (2007): Water Security and Farmer Managed Irrigation System of Nepal, Proceeding of international Seminar, Paper presented at the "Nepal Water Security Forum," radission SAS Hotel, Uppasla, Sweden, Organized by the Silk Road Studies Program at Upasala University, pp. 1-2.

[11] Shukla Ashutosh and Khem R. Sharma (1993): Participatory Irrigation Management in Nepal, A monograph on evolution, process and performance, Ministry of Water Resources, Department of Irrigation, Kathmandu, Nepal, $111 \mathrm{p}$.

[12] Sharma, K. R (2004): Irrigation Conditions, Vision and the Concept of Integrated Water Resources Management System, Management and Training Program, Jawalakhel Lalitpur, Nepal, 134 p.

Discussion open until June 30, 2009 